\title{
Multiple-Text Inscriptions in the Greco- Roman World
}

\begin{abstract}
The concept of multiple-text manuscripts will be tested for its applicability to the epigraphic evidence. On the basis of four specific examples from different cities of the Greco-Roman world, the advantages of this approach will be made clear, as will its limitations.
\end{abstract}

\section{Introduction}

Over the last years, the scholarly interest of manuscriptologists, not only in Hamburg, has been directed far beyond the analysis and commentary of individual handwritings or the study of specific manuscript cultures. A profound comparison of the use of manuscripts in different cultural environments and historical periods was always at the core of the work at the Centre for the Study of Manuscript Cultures. Consequently, the next stage was to move beyond the traditional material of manuscripts (bamboo, palm leaf, parchment, papyrus, etc.), which had been the original focus, and to include the epigraphic evidence: The foundation for joint research between manuscriptologists and epigraphists had been laid. It seemed quite natural to transfer the concepts from the field of manuscript studies to epigraphy. In this way, the two hitherto largely separate fields of research can be brought together and mutually benefit from each other. Manuscripts on the one hand and inscriptions on the other, the exact separation of which can only be defined with great difficulty anyway, thus become 'written artefacts', allowing a new perspective and starting point.

In this contribution, the focus will be on 'written artefacts' that combine more than one text on a single medium. M. Friedrich placed such manuscripts at the centre of an international conference in 2010, the papers of which were united in the edited volume One-volume libraries: Composite and Multiple Text Manuscripts published in 2016. In the introduction, after a thorough examination of various scholarly traditions, M. Friedrich and C. Schwarke offered the following definition: 'multiple-text manuscripts' are codicological units worked in a single operation, whereas composite manuscripts contain formerly independent 
units. ${ }^{1}$ Can epigraphic evidence also be provided for this result? In the following, the practice of placing more than one text on an epigraphic medium will be presented on the basis of a few selected examples. It is rather difficult to find parallels to the composite manuscripts, since in many cases the material properties of the inscribed medium seem to prohibit the combination of various individual 'inscribed written artefacts' as initially separate 'codicological units' to form a new entity. However, if one considers - as in the case of the multiple text manuscripts - an inscribed object as a codicological unit that could unite different independent texts, the number of examples increases considerably. Adapting the concept slightly, we should thus consider cases in which the different texts were united at the same time and possibly even by one hand, as well as cases in which the medium was used over a longer period of time and the multiple text inscription developed piece by piece.

In order to select comparable pieces from the large number of inscriptions from the Greek poleis, epigraphic testimonies are to be examined that contain legal regulations in the broadest sense and were displayed in the public sphere. ${ }^{2}$ Since the population of the city and the visitors to sanctuaries can be understood as the intended audience, the physical characteristics as well as the composition of these written artefacts can be studied and contrasted. The city-state

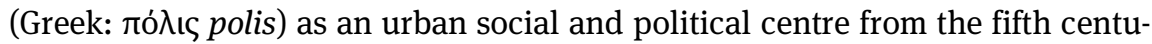
ry BCE to the third century ce was subject to constant changes in its constitution, its social composition and stratification and its political situation. Nevertheless, the relatively small dimension, the concentration on its own citizens and among them the landowners and rich craftsmen and traders, as well as the involvement of the rest of the people in the daily processes, form a stable framework. Inscriptions on stone served as a medium for the permanent transmission of information, and even more so for self-representation to the municipal administration, its individual committees and subdivisions, but also to supra-regional rulers such as the Hellenistic kings and Roman emperors. This raises the question not only of the content of the preserved texts, but also of the context of their placement and display. Were the texts inscribed on specially created writing supports (mostly stelae), were they part of elaborate monuments or were the

1 Friedrich and Schwarke 2016, 15-16.

2 During the summer term 2016 M. Friedrich invited me to present new ideas on epigraphic sources from ancient Greece to the Graduate School at the SFB 950 and I chose the topic of this paper. This first attempt to reconsider well-known inscribed written artefacts has been followed by many more and has introduced me to a new way of approaching Greek and Latin inscriptions. 
walls of public buildings or temples used for their publication? Who was responsible for the selection and composition of the texts as well as for their presentation and placement? Were the individual texts part of a larger collection of regulations or did they stand alone? Finally, from a legal historical perspective, it is important to clarify whether the publication on stone was in any way a prerequisite for the legal validity of the provisions.

\section{The polygonal wall of the temple of Apollon in Delphi (Phocis): Records of manumitted slaves}

The sanctuary of Apollo at Delphi was one of the greatest attractions for the inhabitants of the Greek poleis, not only on the mainland, but also on the islands, in Asia Minor and in Magna Graecia, i.e., Southern Italy. Consequently, it was a preferred site for buildings and monuments that were intended to portray the history of these states in as favourable a light as possible. In many cases, 'written artefacts' were created through the complex combination of architectural, statuary and textual elements, which were intended to leave a lasting impression on visitors. A special feature is a large group of smaller texts that were attached to the retaining wall of the temple terrace, the so-called polygonal wall, facing to the south (Fig. 1). More than a thousand inscriptions attest to the manumission of slaves by Delphians, but also by citizens of other poleis, from the beginning of the second century BCE until the beginning of the first century BCE. From this time onwards, other walls as well as individual writing supports were used for the same genre of texts, which continue into the first century CE. ${ }^{3}$ The texts are records of the deed of manumission, which was performed as a sale involving the manumittor as vendor on the one side and the god Apollo as purchaser on the other, albeit on the condition of freeing the slave. They are dated by naming the priest of the sanctuary thus using the typical formula for Delphic inscriptions. Moreover, they bear the names of witnesses and often even refer to a subscription and therefore convey at least parts of the original contract which seems to have been mixed with formulae of entering it into the acts of the sanctuary's administration. ${ }^{4}$ Since the new status of the

3 An introduction to the system of manumission is to be found in Mulliez 1992, meanwhile the first part of his corpus of the inscriptions has appeared (CID V).

4 Harter-Uibopuu 2013, 281-294 on this compilation of two legally independent texts, which was then engraved on the polygonal wall. 
former slave is mentioned as well as his duties towards the manumittor and the possible protection from re-enslavement, the texts have often been interpreted as safeguards against any offence. Still, the self-presentation of the manumittors within their own community and in the eyes of the visitors cannot be underestimated. ${ }^{5}$

Although there are clearly many texts in one 'codicological unit', i.e. the wall, the question remains whether this can be called a 'multiple-text inscription' or a 'composite inscription' in the sense of the definition used by Friedrich and Schwarke. Only a more precise description of the epigraphic qualities allows an answer here. The wall itself stems from the last quarter of the sixth century BCE and is thus more than 300 years older than the inscriptions. Its main purpose was not to be a medium for public inscriptions, but this possible quality due to its central place in the sanctuary seems to have been acknowledged and exploited later on. For this purpose, individual areas were smoothed time and again, which were then inscribed (Fig. 2). The texts appear quite uniform at first glance, since the letter-sizes are about the same. Nevertheless, they were not only created in different years, but above all they were also applied by different masons. The content of the inscriptions makes it very clear that the publication on stone was not necessary for the legal validity of the manumission act. ${ }^{6}$ Even if in a certain way synchronous 'clusters' were created, there is yet no strict order in which the space had to be used. Repeatedly, inscriptions are added that do not contain manumissions but other public decrees concerning the city and the sanctuary. I would not apply the term 'multiple-text inscription' here, since the polygonal wall contains a collection of texts formed over $c .100$ years. On the other hand, 'composite inscription' would not be appropriate either, because there are no formerly independent units bearing writing. Still, it is definitely one written artefact, a codicological unit binding the different acts together. What was its purpose? The wall was accessible to everybody and may have been a point of reference for the content. The former slaves and their families will have cherished the memory of their change of status, the manumittors were praised for their benevolence and could show this to their peers. Anybody wishing to rely on the help of the sanctuary in freeing their slaves could use the

5 Lepke 2019 analyses the effect of the manumission inscriptions in the sanctuary of Apollo on the basis of the strangers who are recorded there as former owners of the slaves.

6 Harter-Uibopuu 2013, 293-294. 
templates of the records. In this way the wall can be seen as an archive, public not in the sense of an institution, but of its display and accessibility. ${ }^{7}$

\section{The 'archive wall' of Aphrodisias (Caria): self- presentation of a proud city}

The identification of a group of texts at the theatre of Aphrodisias as an 'archive wall' by J. Reynolds in 1982 was rightly criticised subsequently, but the dossier is of great interest for the considerations at stake. ${ }^{8}$ Dominated by the typical invocation АГА $\mathrm{A}$ TYХН ('To good luck') it comprises 21 documents from the period between the Roman general Lucius Cornelius Sulla and the Roman emperor Gordian III ( $243 \mathrm{CE})$, in which various privileges of the Carian city as a civitas libera within the Empire had been granted and confirmed by the Roman authorities. The wall on which they were publicly recorded dates from the late first century BCE and forms the northern end of the stage building. It was 11 metres long and between 2.5 and 5.5 metres high (Fig. 3). ${ }^{9}$ In contrast to the inscriptions on the polygonal wall from Delphi, however, those from Aphrodisias show great uniformity in their lettering and in their placement. Reynolds already pointed out that the letter forms correspond to a good standard for public, but also fine private inscriptions of the second half of the second century CE and the third century CE. The use of 'guiding lines' as well as the careful structuring of the inscription by vertical balks, subtitles, segmentation marks and other visible elements testifies to purposeful planning of the 'visual organization'. Moreover, the texts, mostly letters of Roman emperors, were in some instances shortened

7 A similar phenomenon can be seen in Bouthrotos, an ancient city in Epiros (today Butrint/ Albania), where the manumission records from c. 160-100 BCE are found on the parodos wall of the theatre as well as on architectural blocks later used to build a fortification, cf. I. Bouthrotos. 8 Chaniotis 2003, 251--252 points to the fact that the documents have been carefully selected for presentation on the wall, and that probably many more public documents, which did not fit the story to be told, were deliberately left out. Although the term 'inscription dossier' is frequently used, it is slightly misleading. One might rather speak about an inscribed dossier, since the written artefact is a collection of texts rather than a collection of inscriptions. I will therefore use the simple term dossier.

9 Reynolds 1982, 33-37; Kokkinia 2015-2016, 12-14. The wall was not found intact but had to be reconstructed, using inscribed blocks found in the vicinity. The letters of the invocation are almost three times the size of the ones used for the texts $(0.08 \mathrm{~m}$. as compared to 0.015$0.025 \mathrm{~m}$.), furthermore it is positioned right at the centre of the dossier. 
deliberately by omitting certain standard formulas and concentrating on the central messages. In a careful study of the monument, C. Kokkinia explains the design and the genesis of the written artefact convincingly. She is able to differentiate between two phases of inscribing by criteria of palaeography and other external characteristics. Around the year $224 \mathrm{CE}$, during the reign of Septimius Severus, the first seventeen documents were assembled and incised above the orthostates' course. In 243 or a little later, another four documents were added below this first composition, this time using the orthostates. ${ }^{10}$ While Reynolds sees the chronological order of the documents as a decisive criterion for their place on the 'carrier', and thus has interested visitors start at the top left in col. I and end at the right in col. VI, Kokkinia interprets the arrangement in a different way. The layout seems to be based on the centre of the texts, as the large heading on col. IV suggests. The most important texts were placed there, and individual passages were highlighted by being centred in a separate line. In the two columns on the left and right (III and V) on the other hand, the individual texts were marked by initial letters and more densely inscribed, which automatically drew attention to col. IV. In this way, the praise of Augustus, the first Roman emperor, who had elevated Aphrodisias as his city 'out of all Asia', was given a special position both in terms of content and visual appearance, followed by similar messages. 'Even a quick and half-distracted reader would get the message', Kokkinia asserts. ${ }^{11}$

To my view, this extensive dossier clearly constitutes a 'multiple-text inscription' according to the definition noted at the beginning. In a single operation (enlarged only twenty years later by another one) several texts are carefully chosen, put together and presented as a new unit, with special attention to its visual organization. The publication was authorized by the city herself, who thus chose a way of favourable self-presentation through a sophisticated monument. The wall of the stage building as a written artefact, however, is to be seen in the larger context of the entrance to the theatre. Tributes to outstanding citizens of the city virtually frame the documents inscribed on it. Thus, every visitor to the theatre would not only notice the inscriptions on his left, but also the heroon for Aristokles Molossos, a benefactor from the second century CE, and the statues of Artemidoros, son of Apollonios, and of C. Iulius Zoilos, both first century BCE. Their prominent families also stand out clearly in the documents

10 Kokkinia 2015-2016, 15-20.

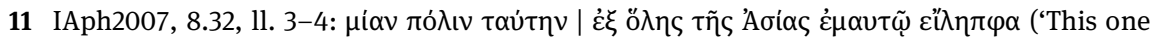
city I have taken for mine out of all Asia'). Kokkinia 2015-2016, 44-47. On the political background and the historical realities see Chaniotis 2003. 
of the dossier. ${ }^{12}$ Therefore, if one wants to compare the wall with a precisely planned and beautifully manufactured multiple-text manuscript, the archaeological and epigraphic context in the theatre entrance is the 'showroom' in which the magnificent gem was displayed.

\section{A petition to Gordianus III from Skaptopara (Thrace): Villagers complaining to their emperor}

Gordian III (225-244 CE), whose letter to the city of Aphrodisias forms the closing of the documents just presented, was also asked by the Thracian community of Skaptopara for help against the attacks of Roman soldiers. His reply to this petition was subsequently published as a bilingual inscription on a stele which was found in 1868 but then lost again only a few years later (Fig. 4). Even a squeeze that had gone to the Archaeological Institute in Athens can no longer be consulted. K. Hallof succeeded in finding a squeeze, sketches and letters in the archives of the Inscriptiones Graecae at the Berlin-Brandenburg Academy of Sciences as well as in Theodor Mommsen's documents left to the Berlin State Library after his death, which allow a critical reading of the lower half of the text and can thus correct and supplement Mommsen's edition in CIL III Suppl. 12336. ${ }^{13}$ Still, for a visualization of the layout of the text on the stele measuring 1 metre in height and 0.7 metre in width one has to rely on Mommsen's description:

Die Disposition der Inschrift ist auffallend und auch für die sachliche Behandlung zu berücksichtigen. Sie begann mit der lateinischen Vormerkung, deren Zeilen offenbar über die ganze Breite der Tafel liefen; dieser Theil ist verloren und die Zeilenabtheilung unbekannt. Darauf folgen die griechischen Texte, in drei schmalen Columnen geschrieben, welchen jetzt allen die Köpfe fehlen; die Columnen setzen einander fort und weder sonst noch am Schluss der dritten begegnen leer gelassene Räume. Unterhalb dieser drei den Mittelraum füllenden Columnen folgt in vier wieder über die ganze Fläche laufenden Zeilen das kaiserliche Rescript; die letzte ist nicht voll und hat den Anschein einer Endzeile. ${ }^{14}$

12 Kokkinia 2015-2016, 14-15 and Reynolds 1982, 149-150 and 156-164.

13 Hallof 1994, 405-413, presenting the intriguing history of the inscription and its transcription, which can itself be gathered from various archived written artefacts in detail.

14 'The disposition of the inscription is striking and should also be taken into account for the purposes of its interpretation. It started with the Latin prescript, the lines of which apparently ran across the entire width of the panel; this part is lost, and the division of the lines is 
There are several distinct elements brought together in the inscription pertaining to different stages of the complaint of the villagers and its treatment by the Roman authorities. As the dossier in Aphrodisias the document in Skaptopara starts with an invocation, this time it is the latinized version bona fortuna of the

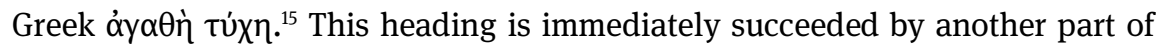
the text, still in Latin, in one single column and probably set in larger letters than the petition itself: the authentication of the copy of the imperial rescript, which was presumably handed to the petitioner Aurelius Pyrrus (1l. 2-5). ${ }^{16}$ The note of receipt from the imperial chancellery (ll. 6-7) serves on the one hand as a means of identifying the petition in response to which the rescript was made, but on the other hand also as an introduction to the Greek text that follows. The two next parts are in Greek and distributed quite evenly over three columns. Column I and two thirds of column II hold the libellus (the petition) of the inhabitants of Skaptopara (11.9-107). They complain to the emperor that soldiers would regularly forcefully exact quarter and lodging from them without adequate payment, even though the village was not actually obliged to provide it. Various orders and edicts from the governor in the past had not helped. They announce that - if there was no improvement - they would have to leave their properties and that this would, of course, be to the detriment of the imperial treasury. ${ }^{17}$ In the lower third of column II and in column III follows the speech of Aurelius Pyrrus (1l. 108-164), who once again vividly describes the facts of the

unknown. This is followed by the Greek texts, written in three narrow columns, all of which are now missing their headings; the columns continue each other, and no empty spaces are found either elsewhere or at the end of the third. Below these three columns filling the middle space, the imperial rescript follows in four lines again running across the entire surface; the last one is not full and has the appearance of an end line' (Mommsen 1892, 245, my translation). The description is the basis of the schematical layout in Hauken 1998, 84, Fig. 5, and his reconstruction of the written artefact, on p. 81.

15 Mommsen 1892, 249; Hauken 1998, 82. This Latin form is mainly used in the Greek provinces of the Roman empire, where the Greek invocation was a common sight to every reader. Since the illustration in this article is a drawing of the surviving squeeze, the first part is missing. It shows the lower half of the monument.

16 This introduction not only provides an exact date for the imperial rescript (16 Dec. 238 CE), but also hints to the practice of the imperial chancellery in Rome to put rescripta on display in the portico of the baths of Trajan (1l.4-5). The procedure of the authentication of the copy is described by Hauken 1998, 98-105 with a detailed commentary and several comparable epigraphic and papyrological sources.

17 On the historical circumstances and the problems of civilians in the Eastern provinces of the Roman Empire throughout second and third century CE cf. Herrmann 1990, 37-48; Hauken 1998, 106-120. 
case in the proceedings before the governor of Thrace and explains why the villagers had turned to the emperor. This part is not only set apart from the former text by a vacat of about three lines, but also introduced by the Latin adlegent, starting a little out of the left margin of the column. Thus, the visual organization underlines the structure of the composed document. The text concludes with the emperor's rescriptio (11. 165-168) - again in Latin and using the full width of the stele and thus clearly set off in the layout - who, however, does not decide the case but instructs the governor to find out the truth. The last line shows also the words rescripsi, reocognovi, signa VI. The first word refers to Gordian III, the emperor, who ascertains that it was he himself who answered to the petition. The second word shows the acknowledgement of the office $a$ libellis, in charge of the correspondence of the emperor. Signa refers to the witnesses attesting that the copy of the rescriptum was correct and hints to the fact that the original papyrus was actually bearing six seals.

Although the inscription would like to convey this impression, the legal record is far from complete nor chronologically narrated. I do not believe that the written artefact in the village reproduces the document on papyrus that was given to the petitioner in Rome, nor is it a faithful copy of the proceedings before the governor. Although the authenticating endorsement and the petition may well have formed the beginning, the imperial rescriptio would have had to have stood between the two Greek texts. It was issued after the petition and - as its content shows - precedes the proceedings before the governor, to whom the whole matter had been referred. On the other hand, its use at the end of the inscription forms the ideal frame for the Greek texts: Beginning with the authorization that what follows is in fact the voice of the emperor and ending with his assertion rescripsi, the written artefact gains importance and authority. An extract from the protocol from the governor's court is quoted verbatim (adlegent forms a typical note in the minutes), but this is only a small part of the proceedings. ${ }^{18}$ It is particularly noticeable that the decision of the governor is missing. A positive outcome for the inhabitants of the village can only be inferred from the fact that the selection of texts was set and published as an inscription in the present form. Of course, this was not necessary for the legal validity of the governor's decision or indeed of the imperial rescriptum.

In this way, several different, deliberately chosen texts are well combined and inscribed in one instance on a carrier which probably has been manufactured especially for this occasion. This is a multiple-text inscription in the best sense. It remains to be asked who was in charge of its creation and who may

18 Hauken 1998, 120. 
have authorized it. One possible originator may have been the village of Skaptopara who had been maltreated and had - successfully - complained to the emperor. After a series of written announcements by the governor, which had not kept the soldiers away, the villagers may have hoped that the imperial authority would now frighten the military enough to leave them in peace. On the other hand, the role of Aurelius Pyrrus is stressed by the layout of the text. He is mentioned with a full description at the top as handing in the petition, and his name appears prominently at the centre at the beginning of the minutes. Thus, he seems to be honoured specifically and may well have been behind the setting up of the written artefact. ${ }^{19}$

\section{The Potamoneion from Mytilene (Lesbos): honouring a rhetor and patriot}

In the troubled times of the first century BCE with regard to the Greek East, the originally friendly relationship between Mytilene on Lesbos and Rome had deteriorated considerably after the Mytilenaeans had sided with Mithradates against Rome in the war (88-85 BCE). It was largely thanks to the personal and close relationship of Theophanes of Mytilene with $\mathrm{Cn}$. Pompeius Magnus that the situation for Mytilene improved again from 62 BCE. The city regained its libertas and was granted further privileges successively. An inscription honours not only Pompeius and Theophanes, the latter as Zeus Eleutherios, but also the third benefactor of the city: Potamon, son of Lesbonax..$^{20}$ It is to his credit that the city was able to maintain its special status even after the discord between Pompey and Caesar. Potamon was a regular participant in diplomatic missions, at first to Caesar, then later to his successor Augustus. He, too, succeeded in gaining privileges such as exemption from taxes and in establishing a cult for

19 Hauken 1998, 82, even presumes that the governor's verdict might not have been as positive as the villagers had hoped and that Aurelius Pyrrus took the initiative personally to have the inscription published even despite of this fact. Although his role may have been decisive, I do not believe that he would have put his failure (he was the representative) in such a way on display in a small community where everybody knew the context.

20 Pawlak 2020, 173-180 on the political circumstances and the vita of Theophanes (IG XII 2, 163) on the display of the texts on the monument. 
Augustus in addition to the cult of Roma in his homeland..$^{21}$ For the present article, however, it is not so much these diplomatic successes that are of importance, but rather the special honours bestowed on Potamon. In addition to the usual honorary inscriptions, praising him as benefactor, saviour and found-

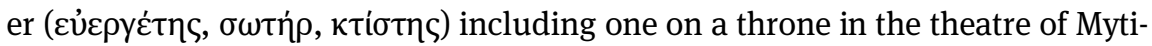
lene, a large monument bearing the name Potamoneion was situated on the Acropolis. ${ }^{22}$ The editor of the Lesbian inscriptions, William Paton, attempts to reconstruct the monument, which had been destroyed during an earthquake and whose stones had subsequently been reused in the walls of the fort on the Acropolis. He assumes a base consisting of at least three layers of blocks on which the texts were carefully inscribed in several columns with large and elegant letters. More than 60 fragments of inscriptions can be attributed to it on account of the very distinctive and elegant writing and the characteristics of the stone. They were all engraved at the same time and probably by the same mason, arranged in at least five columns. The ensemble is structured by headlines (in col. b 1. 6; col. b 1.13; col. b 1. 36) as well as by the phenomenon of hanging lines in column $\mathrm{c}^{23}$

The monument probably bore all the decrees of the city, letters from Rome and other official documents that mentioned Potamon's name, provided information about his activities and attested to the corresponding honours by the city. The documents cover a period from the Battle of Pharsalos (48 BCE) to the reign of Augustus (27 $\mathrm{BCE}-14 \mathrm{CE}$ ), when the honoured was the first imperial priest in Mytilene. The dossier of inscriptions also contains various senatus consulta: the first is referred to in a letter by Caesar, dating from 46-45 BCE. In it, the dictator reports to the Mytilenaeans on the success of their legation, which was able to obtain a senate resolution on the renewal of the status amicus et socius, but also transmitting his own edictum on taxation matters. The two

21 Pawlak 2020, 180-187; Parker 1991 provides a concise portrait of Potamon and analyses the epigraphic evidence for his family and descendants. Several literary sources mention Potamon, collected in BNJ 147 (<dx.doi.org/10.1163/1873-5363_bnj_a147>, accessed on 27 Jan. 2021).

22 Parker 1991, 121 refers to the honours: IG XII 2, 272 (throne); 159-163 (honorary inscriptions). The name 'Potamoneion' is mentioned in IG XII 2, 51, 1. 5, one of the fragments belonging to the structure.

23 IG XII 2, 23-57; IG XII suppl. 6-12 and 112; Cf. Mommsen 1895, 890-891; Parker 1991, 115 n. 2; and Dimopoulou-Piliouni 2010, 35 on the history of the epigraphical research. Hodot 1982, 187 describes the following characteristics: 'lettres élégantes avec apices de 15 à $20 \mathrm{~mm}$ de hauteur [...] interlignes spacieux [...] forme particulière de l'éta, avec barre médiane incurvée, [...] succession des documents sur la même pierre avec des intertitres détachés au milieu d'une ligne'. 
senatus consulta, which are reproduced probably verbatim immediately below date to the year $25 \mathrm{BCE}$.

Even though the memorial and the texts it contained represent an important documentary source for the history of the island, the administration of the Roman Empire in the early Principate and, not least, for the transmission and publication of state acts from the capital to the provinces, this is not its original intention. Rather, the installation of such a monument of honour must be considered as the result of a form of negotiation between the two parties involved, the honoured person and his family on the one hand and the polis on the other. Potamon was arguably one of the most important citizens of the city and had dedicated his life and probably large parts of his assets to its service. He deserved the same honours as other benefactors in similar situations, not only in Lesbos but all around the Greek cities of the Roman Empire. Since the exact date of the placement of the monument is not known, it cannot be said with certainty whether he himself was still able to influence the design, or whether his descendants did so. In any case, the practice of arranging and setting up honorary monuments and inscriptions since Hellenistic times suggests communication. Still, not only the honorands, but also the city was presented in the most positive light possible. In the same way as in the case of the theatre wall in Aphrodisias, the elevated status of the Mytilene among the subjects of the new Roman Emperor Augustus was presented to the public, as the deliberate headlines clearly point out. Any visitor would perceive not only the fame of Potamon, son of Lesbonax, but also the glory of the polis. ${ }^{24}$ The Potamoneion is an impressive multiple-text inscription, a written artefact combining different texts from different periods in one codicological unit. Its placement on the acropolis of Mytilene suggests the appropriate setting amongst shrines and other monuments.

\section{Conclusion}

Not every written artefact containing more than one inscription can be classified as a multiple-text inscription, thus corresponding to the concept of multipletext manuscript. Still, once one starts to look at the characteristics that have been developed through manuscript research, new possibilities for analysing

24 Eck 2014 compares the dossier to those of Iason of Kyaneiai in Lycia or T. Sennius Sollemnis in Aragenua in Gallia Lugdunensis and stresses that these inscriptions are not publications in any legal sense but presentations. 
the so-called inscription dossiers and understanding them as elaborate creations open up. While the polygonal wall in the sanctuary of Delphi lacks the necessary unity of production, the theatre wall in Aphrodisias, the stele from Skaptopara in Thrace and the Potamoneion from Mytilene are close parallels to the concept presented by M. Friedrich and C. Schwarke in 2016. The search for a 'composite inscription' has up to now been unsuccessful and remains a research question to be solved.

\section{Abbreviations}

BNJ

CID V

IAph2007

IG XII 2

IGBulg IV
I. Bouthrotos Pierre Cabanes and Faik Drini (eds), Corpus des Inscriptions grecques d'llyrie

Ian Worthington (gen. ed.), Brill's New Jacoby, Leiden: Brill, 2017

<referenceworks.brillonline.com/browse/brill-s-new-jacoby>.

Dominique Mulliez (ed.), Corpus des Inscriptions de Delphes, V: Les actes d'affranchissement, 1, Athens: École française d'Athènes, 2019.

Joyce Reynolds, Charlotte Roueché and Gabriel Bodard, Inscriptions of Aphrodisias, online-edition <http://insaph.kcl.ac.uk/iaph2007/index.html> (accessed on 19 April 2021). méridionale et d'Épire, II/2: Inscriptions de Bouthrôtos, Athens: École française d'Athènes, 2007.

William R. Paton (ed.), Inscriptiones Graecae, XII: Inscriptiones insularum maris Aegaei praeter Delum, 2: Inscriptiones Lesbi, Nesi, Tenedi, Berlin: De Gruyter, 1899.

Georgi Mihailov (ed.), Inscriptiones graecae in Bulgaria repertae, IV: Inscriptiones in territorio Serdicensi et in vallibus Strymonis Nestique repertae, Sofia: Academia Litterarum Bulgarica, 1966.

\section{References}

Chaniotis, Angelos (2003), 'The Perception of Imperial Power in Aphrodisias: The Epigraphic Evidence', in Lukas de Blois et al. (eds), The Representation and Perception of Roman Imperial Power. Proceedings of the Third Workshop of the International Network Impact of Empire (Roman Empire, c. 200 B.C. - A.D. 476), Rome, March 20-23, 2002 (Impact of Empire, 3), Leiden: Brill, 250-260.

Dimopoulou-Piliouni, Athina (2010), 'Communiquer avec le pouvoir romain: les lettres de Jules César publiées par la cité de Mytilène', Revue internationale des droits de l'Antiquité, 57: 33-49. 
Eck, Werner (2014), Judäa - Syria Palästina. Die Auseinandersetzung einer Provinz mit römischer Politik und Kultur (Texts and Studies in Ancient Judaism, 157), Tübingen: Mohr Siebeck.

Friedrich, Michael and Cosima Schwarke (2016), 'Introduction - Manuscripts as Evolving Entities', in Michael Friedrich and Cosima Schwarke (eds), One-Volume Libraries: Composite and Multiple-Text Manuscripts (Studies in Manuscript Cultures, 9), Berlin: De Gruyter, 1-26.

Hallof, Klaus (1994), 'Die Inschrift von Skaptopara. Neue Dokumente und neue Lesungen', Chiron, 24: 405-441.

Harter-Uibopuu, Kaja (2013), 'Epigraphische Quellen zum Archivwesen in den griechischen Poleis des ausgehenden Hellenismus und der Kaiserzeit', in Michele Faraguna (ed.), Archives and Archival Documents in Ancient Societies (Legal Documents in Ancient Societies, 4), Trieste: EUT, 273-305.

Hauken, Tor (1998), Petition and Response. An Epigraphic Study of Petitions to Roman Emperors 181-249 (Monographs from the Norwegian Institute at Athens, 2), Bergen: The Norwegian Institute at Athens.

Herrmann, Peter (1990), Hilferufe aus römischen Provinzen. Ein Aspekt der Krise des römischen Reiches im 3. Jhdt. n. Chr. (Berichte aus den Sitzungen der Joachim Jungius-Gesellschaft der Wissenschaften e.V., Hamburg, 8/4), Göttingen: Vandenhoeck \& Ruprecht.

Hodot, René (1982), 'Deux notes sur des inscriptions de Mytilène', Zeitschrift für Papyrologie und Epigraphik, 49: 187-189.

Kokkinia, Christina (2015-2016), 'The design of the "archive wall” in Aphrodisias', Tekmeria, 13: 9-55.

Lepke, Andrew (2019), 'Vor fremden Göttern? Religiöse Handlungs- und Repräsentationsorte im Spiegel der Freilassungsinschriften des 2. Jh.s v. Chr.', in Klaus Freitag and Matthias Haake (eds), Griechische Heiligtümer als Handlungsorte, Stuttgart: Franz Steiner, 279-301.

Mommsen, Theodor (1892), 'Gordians Decret von Skaptoparene,' Zeitschrift der SavignyStiftung für Rechtsgeschichte. Romanistische Abteilung, 12: 244-267.

Mommsen, Theodor (1895), 'Das Potamon-Denkmal auf Mytilene', Sitzungsberichte der königlich preussischen Akademie der Wissenschaften zu Berlin, 1895: 887-901.

Mulliez, Dominique (1992), 'Les actes d'affranchissement delphiques', Cahiers du Centre Gustave Glotz, 3: 31-44.

Parker, Robert (1991), 'Potamon of Mytilene and His Family', Zeitschrift für Papyrologie und Epigraphik, 85: 115-129.

Pawlak, Marcin N. (2020), 'Theophanes, Potamon and Mytilene’s Freedom', Electrum, 27: 173188 <dx.doi.org/10.4467/20800909EL.20.009.12799>.

Reynolds, Joyce (1982), Aphrodisias and Rome (Journal of Roman Studies Monographs, 1), London: Society for the Promotion of Roman Studies. 


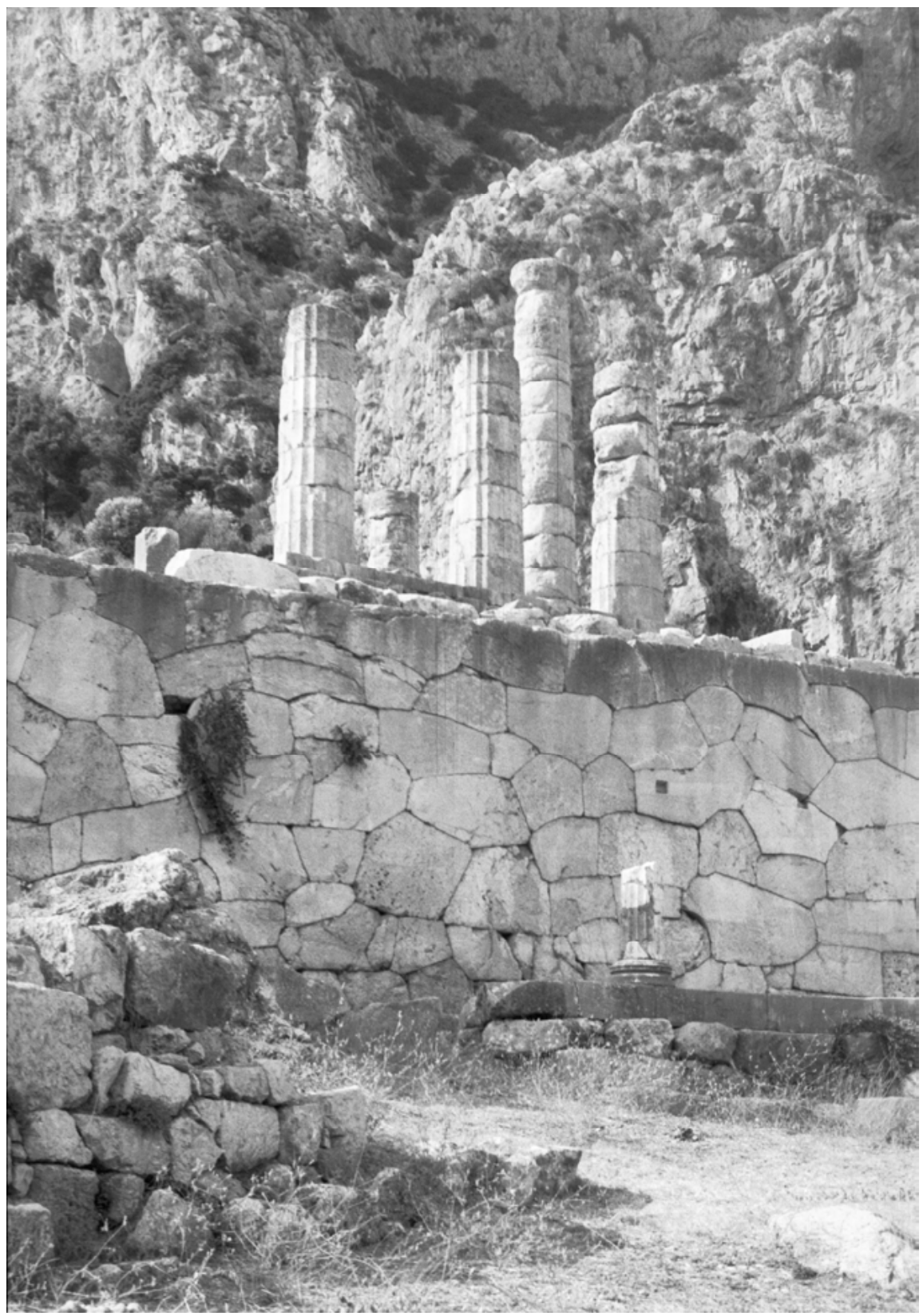

Fig. 1: Delphi, polygonal wall and the temple of Apollo; <https://commons.wikimedia.org/wiki/ File:Supporting_polygonal_masonry_of_Temple_of_Apollo,_Delphi,_Dlfi301.jpg> (accessed on 19 April 2021). CC-BY-SA-4.0. 


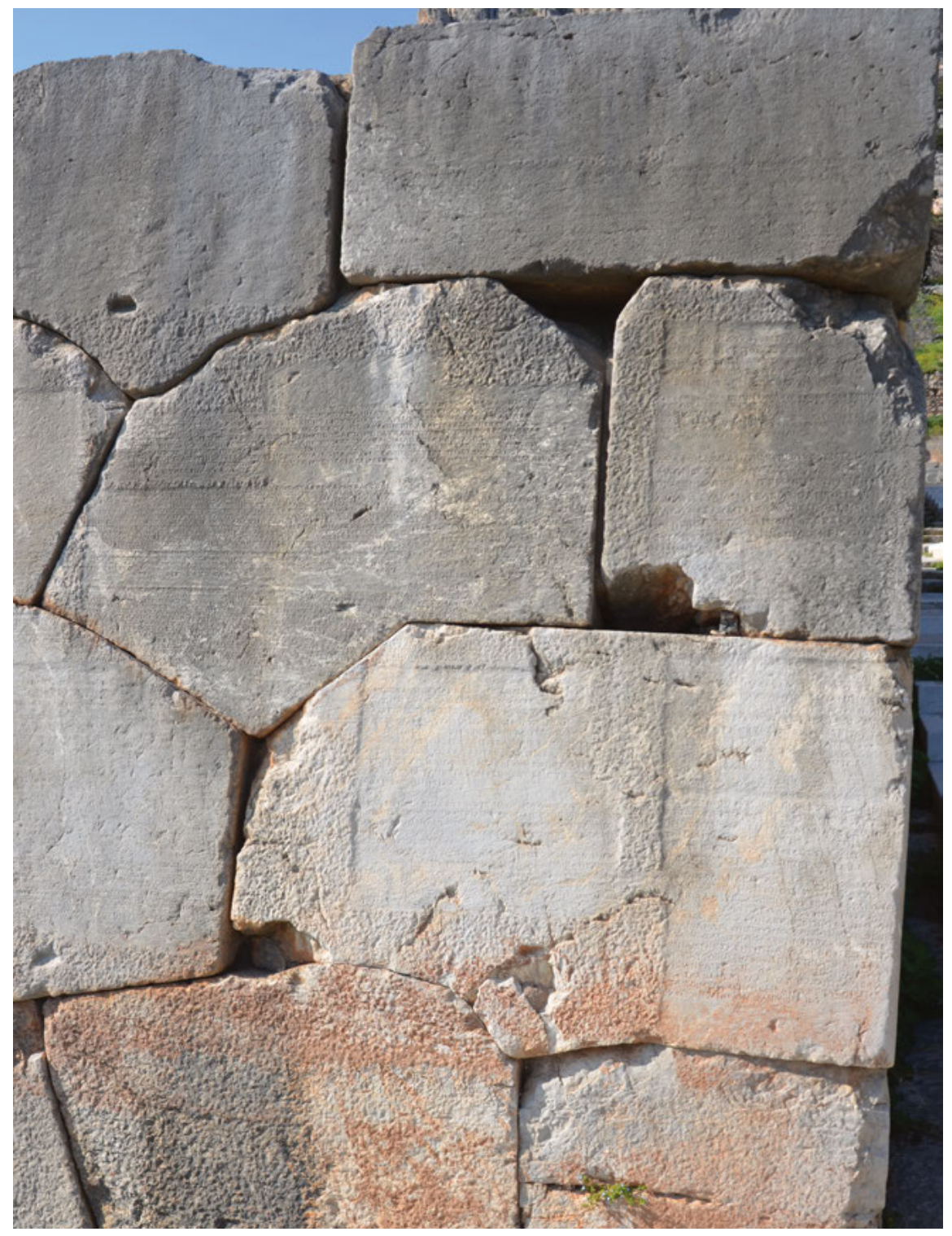

Fig. 2: Delphi, manumission inscriptions on the polygonal wall. ( Julian G. Schneider. 


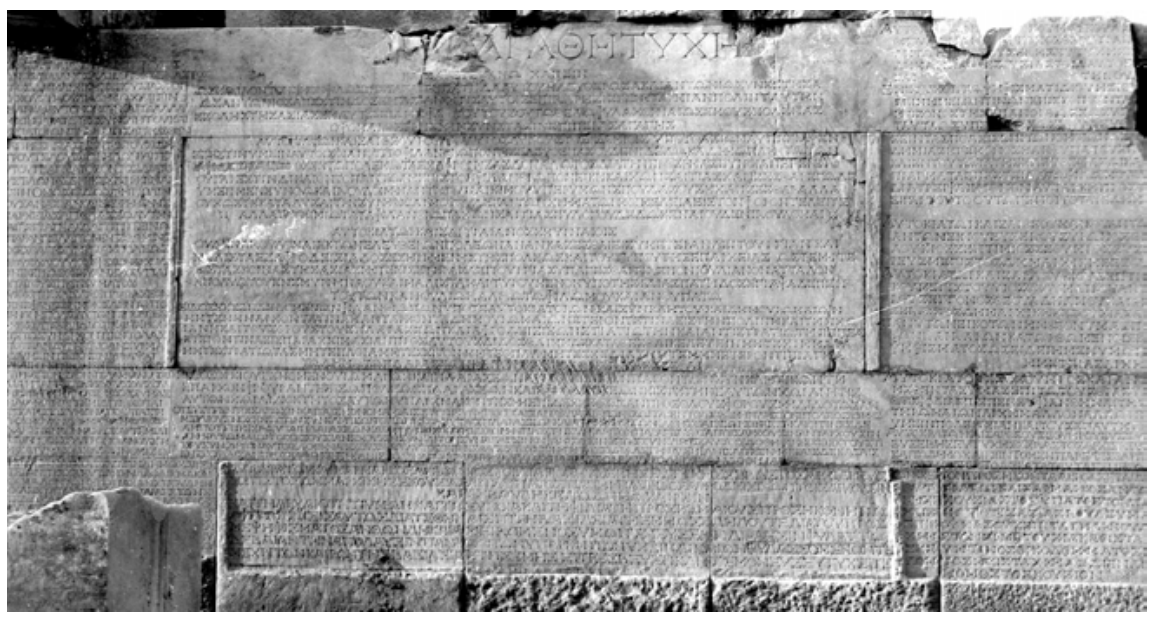

Fig. 3: Aphrodisias, theatre-wall, IAph2007 8.32. (c) Charlotte Roueche.

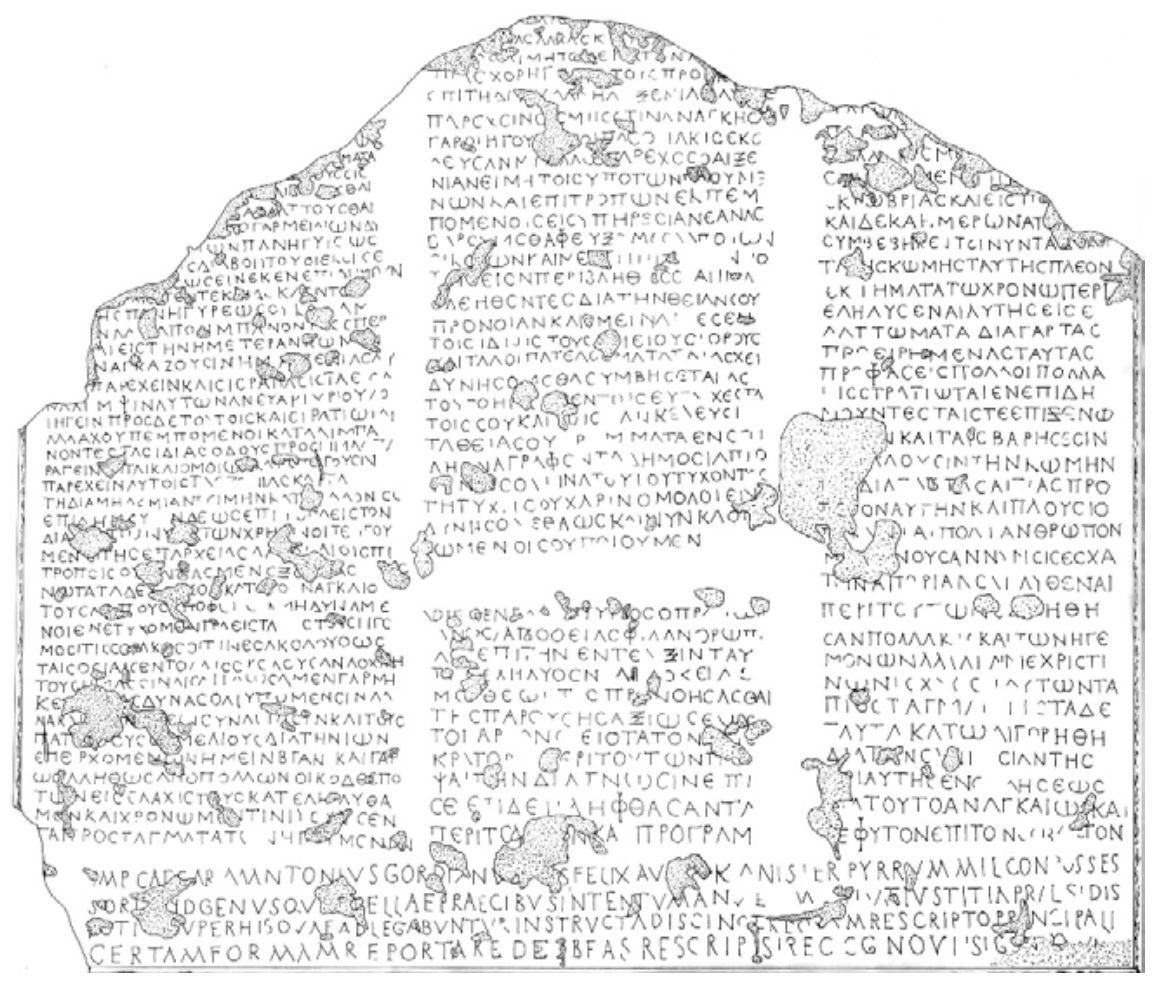

Fig. 4: The sketch of the inscription from Skaptopara. (c) Klaus Hallof. 
